\title{
Zoogeography of primates in insular Southeast Asia: species-area relationships and the effects of taxonomy
}

\author{
Vincent Nijman ${ }^{1,2}$ and Erik Meijaard ${ }^{3,4}$ \\ ${ }^{1}$ Oxford Brookes University, School of Social Sciences and Law, Department of Anthropology and Geography, \\ OX30BP Oxford,UK,vnijman@brookes.ac.uk \\ ${ }^{2}$ University of Amsterdam, Zoological Museum Amsterdam, Mauritskade 61, 1092 AD, Amsterdam, The Nether- \\ lands \\ ${ }^{3}$ The Nature Conservancy, Indonesia Forest Program, Jalan Polantas no. 5, Markoni, Balikpapan 76112, East \\ Kalimantan, Indonesia \\ ${ }^{4}$ Australian National University, School of Archaeology and Anthropology, Building 14, Canberra, ACT 0200, \\ Australia,emeijaard@tnc.org
}

Key words: endemism, extinction, island biogeography, phylogeny, species concepts, Sunda Shelf

\begin{abstract}
Given its complex zoogeography and large number of islands insular Southeast Asia makes an excellent subject for studying the interrelationships of species richness, island area and isolation. The islands are merely highpoints of an immense shallow continental shelf which during Pleistocene glacial periods was exposed periodically as dry land connecting the now isolated islands with one another. The area is home to a large number of primate taxa, including many endemic to the region (Nasalis, Presbytis, Pongo, Symphalangus, Simias, Tarsius). Worldwide, the number of described (extant) species of primates has doubled in the last two decades partially as a result of applying a different species concept (viz. Phylogenetic Species Concept PSC as opposed to the Biological Species Concept BSC). According to Isaac et al. (Trends in Ecology and Evolution 19: 464-469, 2004) this 'taxonomic inflation' will influence the outcome of macroecological studies. We studied the species-area relationships in Primates on 118 islands in insular Southeast Asia, and used two taxonomies (PSC and BSC). The number of primate species (PSC 37 species, BSC 23 species) is highly significantly related to surface area of the islands, and the slope of the curve is similar for both PSC and BSC species $(z=0.13)$. Species 'newly' described under the PSC are not only from large islands but also smaller ones hence affecting neither intercept nor the slope of the curve. Area alone was a much better predictor for primate species richness than models that included other macroecological variables (latitude, longitude, altitude, distance to mainland, greatest depth between island and mainland, distance to neighbouring islands). Degree of isolation has little influence on species number but both longitude and latitude are inversely correlated with the number of species per island, suggesting that species numbers decrease in a northerly and easterly direction. The low z-values suggest that for primates the islands of Southeast Asia are perhaps less isolated than previously recognised.
\end{abstract}

\section{Contents}

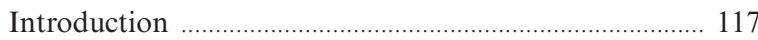

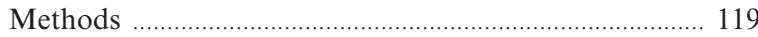

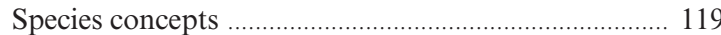

Distributional data ……................................................. 119

Species area relationships .......................................... 121

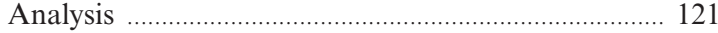

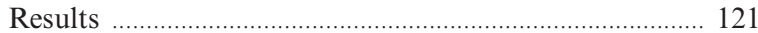

Choice of taxonomy …………………………………..... 121

Effect of geographical variables ..................................... 122

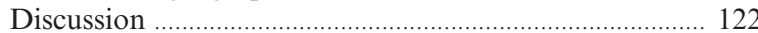

Species-area relationships ………………………………. 122

Taxonomy and slope ………………………………….... 123

Conclusion and avenues for further research ............... 124

Acknowledgements …………………………………….... 124

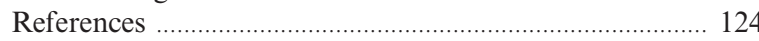

\section{Introduction}

Small areas, islands or otherwise, are expected to harbor fewer species than large areas. Since the 1920s ecologists have tried to fit equations to such species-area relationships. The most powerful model that has been in use since the 1960s (e.g. Preston $1960,1962)$ is a power-function model, usually expressed as a double logarithmic transformation, log $\mathrm{S}=\log \mathrm{k}+\mathrm{z} \log \mathrm{A}$, where $\mathrm{S}$ represents the number of species, $\mathrm{A}$ is the (island) area, and $\mathrm{k}$ and $\mathrm{z}$ are fitted parameters that describe intercept (where the extrapolated fitted line intercepts the species number axis, i.e. when area 'is zero' reflecting the overall species richness of the study area) and slope (increase 
in species number as the area increases). The power function is derived from a $\log$ normal distribution of species abundance, and the theory that supports the use of this function (e.g. Preston, 1960, MacArthur and Wilson, 1967) contains the implicit assumption of equilibrium. A large number of studies have established the validity of this relationship. As a rule of thumb, for islands the values of the exponent z normally ranges from $0.24-0.34$ (land-bridge islands tend to have smaller values than oceanic islands) and those for mainland samples falls within the range of 0.12-0.17 (MacArthur and Wilson, 1967; Huggett, 2004) (Fig. 1).

A crucial parameter in studying species area relationships is an accurate knowledge of the distribution of taxa on the different islands. When a larger number of islands are included in the analysis this may become more of a problem, but this can be substantially reduced by focusing on the few relatively well-known taxa. We address the species-area relationships in insular Southeast Asia at a finer scale than those of many previous analyses by including a large number of islands and by studying a small group of species, primates. In comparison with many other taxa, primates are mostly large, easily observable, diurnal species. They are thus relatively well studied (Rowe, 1996).

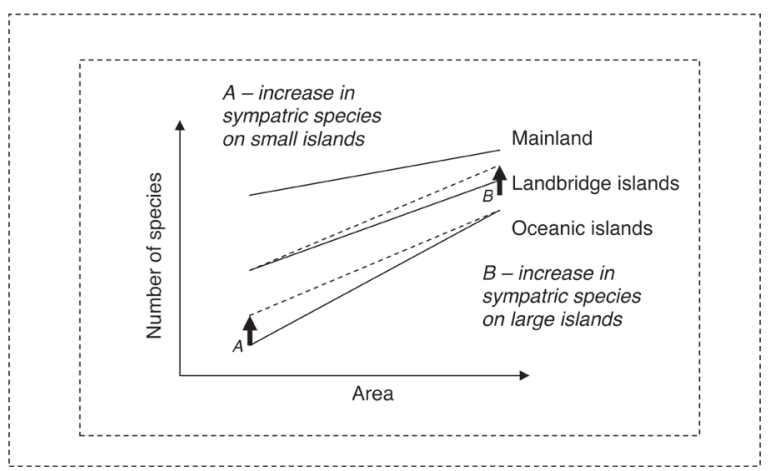

Fig. 1. Equilibrium representation of island species-area relationships for a hypothetical archipelago. The effects of recurrent colonization and extinction produce a steepening of the speciesarea curves with increasing distance: extinction has a greater relative impact on remoter islands for which immigration is increasingly difficult. In situation A there is an increase in the number of described species on small islands (for illustrative purposes Oceanic Islands) leading to a decrease in the slope (dashed line), whereas in situation B there is an increase in number of described species on large islands (for illustrative purposes Land bridge Islands) leading to an increase in the slope (dashed line).
While one would expect that there would be a broad consensus, at least among primatologists, as to what comprises a primate species and, roughly, how many extant species of primates there are, the number of described species of primates has doubled in the last two decades (Isaac et al., 2004). This is in part driven by better sampling of taxa (e.g. Nekaris and Jaffe, 2007), changing perceptions on what comprises a species (Groves, 2004; Tattersall, 2007), and increasingly the use of DNA sequence diversity to identify species (e.g. Zain, 2001, Roos, 2003, Geissmann et al., 2004, Steiper, 2006, Chu et al., 2007, Ziegler et al., 2007).

The description of new species may affect species-area relationships in different ways, depending on their nature and their area of occurrence. If the newly described species exclusively occur allopatrically on islands, with their congeners occurring on other such islands or the mainland, the effect of an increase in species number will be limited. Alternatively, if the new species mainly comprise species that co-occur with congeners on islands (either sympatrically or allopatrically) the increase can have an effect if it is not proportional to the number already occurring on islands. In the latter case if the new species are mainly described from the few large islands in the region the slope of the species-area relationship will increase (situation A in Fig. 1), whereas if they are mainly described from small islands this will lead to a decrease in slope (situation B in Fig. 1).

Isaac et al. (2004) drew attention to the danger of 'taxonomic inflation' on our understanding of macroecological patterns (and conservation), i.e. when known subspecies are raised to species as a result in a change of species concept (e.g. from BSC to PSC; see Methods). They noted that taxonomic inflation will lead to a faster increase in species richness in large areas compared to small areas, and hence, species-area curves would become steeper following taxonomic inflation (situation B in Fig. 2). Furthermore, taxonomic inflation leads to a large sample size increasing the analytical power in hypothesis testing.

In the light of the increase in described primate species, Harcourt $(1999,2000)$ concluded that for comparative purposes, genera/area analyses might be more useful than species/area analyses, because genera are taxonomically more stable, perhaps more comparable across deeper taxa, and might be a better indication of degree of variability. 
Due to its dynamic geological past (Holloway and Hall, 1992), relatively stable climates (GathorneHardy et al., 2002) and associated rapid speciation processes (Whitmore, 1987), the Southeast Asian islands are among the richest islands in the world in terms of biodiversity (Myers et al., 2000). The zoogeographical unit of this area is named Sundaland, which refers to the geological area of the Sunda Shelf, i.e. the Thai-Malay Peninsula south of the Isthmus of Kra, the larger islands of Sumatra, Borneo, Palawan and Java, and many smaller islands. A large number of the islands of Sundaland are merely highpoints of an immense shallow continental shelf. During the Pleistocene the shelf was exposed periodically as dry land (during glacial periods) connecting the now isolated islands with one another. During the last glacial maximum, when sea levels were much lower than they are today, all of Sundaland was connected into one large landmass (Molengraaff and Weber, 1920; Tjia, 1980; Geyh et al., 1979). Beaufort (1926), Heaney (1985), and MacKinnon et al. (1996), amongst others have characterized Sundaland as an area through which most species could freely move during glacial periods. Others such as Brandon-Jones (1996a), Inger and Voris (2001), Meijaard (2003b) and Bird et al. (2005), however, recognized that, during much of the Pleistocene, dispersal between the landmasses of Sundaland, especially by terrestrial species, was limited because of barriers created by large rivers and more open vegetation types that replaced rainforests during the cool and dry glacial maxima.

Given its complex zoogeography (e.g. Heaney, 1984; Meijaard, 2003a, b) the area makes an excellent subject for studying the interrelationships of species richness, island area and isolation (Wallace, 1876; MacArthur and Wilson, 1967; Wilcox, 1980; Heaney, 1984, 1986; Harcourt, 1999; Harrison et al., 2006). As summarized by Harcourt (1999), these studies indicate that island area in Southeast Asia correlates positively with species number. Specifically, the double-log slope of island vs. species number was both lower and steeper for islands than for mainland areas, and neither distance to the main source areas (mainland or the largest islands), nor depth of the sea channels between source areas and islands explained the number of mammalian species present on islands. From this we can conclude that the species area relationships for non-volant mammals is a result of extinction only (after the rise of sea levels that isolated the islands) and do not reflect a balance between extinction and immigration (Heaney, 1984).

Here we set out to explore species-area relationships for primates in Sundaland using species lists based on different species concepts.

\section{Methods}

\section{Species concepts}

We created two lists of all primate species occurring in insular Southeast Asia. The first one is based on the Biological Species Concept (Mayr, 1942: p. 120 - 'species are groups of actually or potentially interbreeding natural populations which are reproductively isolated from other such groups') as presented by Groves (1993). The second one is based on the Phylogenetic Species Concept (Cracraft 1983: p. 170 - 'a species is the smallest diagnosable cluster of individual organisms within which there is a parental pattern of ancestry and decent') as presented by Groves (2001) supplemented by more recent research explicitly or implicitly employing the PSC (Meijaard and Groves, 2004; Roos et al., 2003; Chen et al., 2006; Nekaris and Jaffe, 2007; Ziegler et al., 2007 note that these authors themselves do not necessarily name the species) (Table 1). The BSC list contains 23 species, the PSC list 37: the difference is due to a better understanding of phylogenetic relationships (aided by molecular techniques) and a different view of what comprises a species and not due to the discovery of hitherto unknown species.

\section{Distributional data}

Meijaard (2003b) compiled data on the distribution of mammals on 215 small islands $(<12,000$ $\mathrm{km}^{2}$ ) in Southeast Asia. To this we added the three large Sunda Islands of Java, Sumatra and Borneo, as well as the Thai-Malay Peninsula south of the Isthmus of Kra. Islands north of the Isthmus of Kra (here taken as $10^{\circ} 30^{\prime} \mathrm{N}$ ) were excluded. During the last glacial maximum (LGM), ending c $10 \mathrm{ka}$, when sea levels were much lower than today, all individual land areas of Sundaland were connected into one large land mass (exceptions are those islands that are separated from the main Sunda landmass by waters deeper than $120 \mathrm{~m}$, such as the Mentawai Islands off west Sumatra - Voris, 2000). Molecular studies of primates, comparing timing 
Table 1. List of species included in the study following two taxonomic arrangements (see text for details). Endemics (i.e. species occurring on $<5$ islands excluding species occurring extralimital into mainland Asia) are indicated in italics.

\begin{tabular}{|c|c|c|c|c|}
\hline common name & BSC (Groves 1993) & Islands & PSC (Groves 2001, plus additions) & Islands \\
\hline \multirow[t]{4}{*}{ slow loris } & \multirow[t]{4}{*}{ Nycticebus coucang } & \multirow[t]{4}{*}{22} & Nycticebus coucang & 13 \\
\hline & & & N. hilleri & 1 \\
\hline & & & N. menagensis & 7 \\
\hline & & & N. javanicus & 2 \\
\hline western tarsier & Tarsier bancanus & 7 & Tarsier bancanus & 7 \\
\hline long-tailed macaque & Macaca fascicularis & 105 & Macaca fascicularis & 105 \\
\hline \multirow[t]{4}{*}{ pig-tailed macaque } & \multirow[t]{4}{*}{ M. nemestrina } & \multirow[t]{4}{*}{18} & M. nemestrina & 14 \\
\hline & & & M. leonina & 2 \\
\hline & & & M. pagensis & 1 \\
\hline & & & M. siberu & 3 \\
\hline proboscis monkey & Nasalis larvatus & 4 & Nasalis larvatus & 4 \\
\hline simakobu & Simias concolor & 5 & Simias concolor & 5 \\
\hline \multirow[t]{5}{*}{ banded leaf monkey } & \multirow[t]{5}{*}{ Presbytis melalophos } & \multirow[t]{5}{*}{14} & Presbytis melalophos & 6 \\
\hline & & & P. femoralis & 6 \\
\hline & & & P. siamensis & 3 \\
\hline & & & P. natunae & 1 \\
\hline & & & P. chrysomelas & 1 \\
\hline \multirow[t]{3}{*}{ Hose's leaf monkey } & \multirow[t]{3}{*}{ P. hosei } & \multirow[t]{3}{*}{1} & P. hosei & 1 \\
\hline & & & P. sabana & 1 \\
\hline & & & P. canicrus & 1 \\
\hline white-fronted leaf monkey & P. frontata & 1 & P. frontata & 1 \\
\hline red leaf monkey & P. rubicunda & 2 & P. rubicunda & 2 \\
\hline Thomas' leaf monkey & P. thomasi & 1 & P. thomasi & 1 \\
\hline Javan leaf monkey & P. comata & 1 & P. comata & 1 \\
\hline Mentawai leaf monkey & P. potenziani & 4 & P. potenziani & 4 \\
\hline Javan langur & Trachypithecus auratus & 3 & Trachypithecus auratus & 3 \\
\hline silvered langur & T. cristatus & 15 & T. cristatus & 15 \\
\hline dusky langur & T. obscurus & 7 & T. obscurus & 7 \\
\hline Javan gibbon & Hylobates moloch & 1 & Hylobates moloch & 1 \\
\hline Kloss'gibbon & H. klossi & 4 & H. klossi & 4 \\
\hline lar gibbon & H. lar & 2 & H. lar & 2 \\
\hline \multirow[t]{2}{*}{ agile gibbon } & \multirow[t]{2}{*}{ H. agilis } & \multirow[t]{2}{*}{3} & H. agilis & 2 \\
\hline & & & H. albibarbis & 1 \\
\hline Muller's gibbon & H. muelleri & 1 & H. muelleri & 1 \\
\hline siamang & Symphalangus syndactylus & 2 & Symphalangus syndactylus & 2 \\
\hline \multirow[t]{2}{*}{ orangutan } & \multirow[t]{2}{*}{ Pongo pygmaeus } & \multirow[t]{2}{*}{2} & Pongo pygmaeus & 1 \\
\hline & & & P. abelii & 1 \\
\hline
\end{tabular}

of separation between sister taxa, suggests that speciation happens at a time-scale significantly larger than 10 ky (Zain, 2001; Roos, 2003; Chatterjee, 2006; Steiper, 2006; Chu et al., 2007; Ziegler et al., 2007), and hence we anticipate that during the LGM most, if not all, species of primates currently present in Sundaland coexisted on this land mass. For analysis we calculated the area of Sundaland when emerged (excluding the Mentawai Islands), and included this in our analysis.

For each island we tallied the number of primate species that were recorded, discarding cases of likely introduction by humans, in particular long-tailed and, to a lesser extent, pig-tailed macaques (see results). On some islands (e.g. Borneo, Java) many species appear to occur sympatrically in at least part of their distribution range (Brandon-Jones, 1996b; Nijman, 1997, 2000, 2004, 2006; Meijaard and Groves, 2004) whereas on other islands (e.g. Sumatra, Thai-Malay Peninsula) they occur mostly allopatrically (Brandon-Jones, 1996b; Chivers, 1980); we did not take this into account in our analysis. Islands with no primate species present were omitted. This resulted in the inclusion of 118 islands plus the Thai-Malay Peninsula and Sundaland, with a total of 268 records of species presence on these islands 


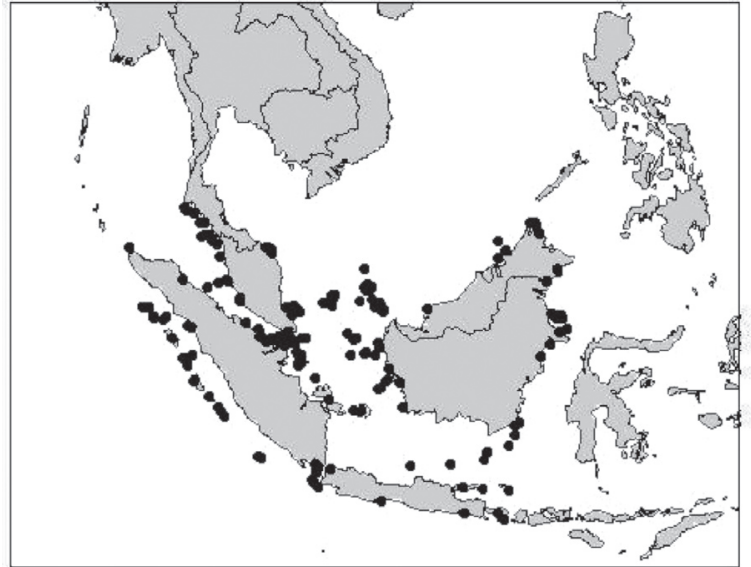

Fig. 2. The 118 islands in insular Southeast Asia for which the primate species numbers were assessed.

(Fig. 2). Species that occurred on five or less islands were considered 'island endemics' (as opposed to e.g. 'geopolitical endemics' or 'restricted-range endemics') excluding species that ranged further north into southeast Asia.

\section{Species area relationships}

Whittaker and Fernandez-Palacios (2007) pointed out that different authors mean different things when they talk about species-area relationships. We limit ourselves to the analysis of the number of species found on each of a set of distinct islands in relation to the area of each unit, viz. our design is nonnested. Since it is debatable whether or not the Thai-Malay Peninsula behaves as an island and since inclusion of Sundaland makes the design nested, we discuss these cases separately.

While our model contains the implicit assumption of equilibrium, we note that the area of most of at least the smaller islands must have changed in a rather dynamic fashion since the LGM as a function of both sea-level rise and the topography/hypsometry of each island. Some islands may have been effectively 'small' for a long time (i.e. those with steep offshore bathymetry) whereas others may have been large and became small only a few millenia ago (i.e. those with variable or shallow offshore bathymetry), and this may have an effect on extinction patterns. As a proxy for this we included, besides area, altitude (islands with steep offshore bathymetry are expected to have high mountains) and greatest depth between island and mainland in our set of predictor variables.

\section{Analysis}

We used simple linear regressions and multiple regressions to explore relationships between island size and number of species present on these islands. To approach a normal distribution more closely most variables were log-transformed prior to analysis. To find out which variables strongly correlated with number of species, we investigated the relationships among different macroecological variables (latitude, longitude, altitude, distance to mainland, greatest depth between island and mainland, distance to neighbouring islands, as well as island size) using the number of PSC species per island as the dependent variable. We conducted regressions using Pearson Correlation to measure to strength of associations. To assess the colinearity between our variables which could have confounded our results, we examined plots of all variables plotted against all others and determined the bivariate correlations between each of the variables. This procedure identified several correlated variables (see Results), and we determined the independent effects of predictor variables and PSC species numbers through multiple regression analyses. Analyses were done in SPSS 13.0 (SPSS 2004). Significance is accepted when $\mathrm{P}<0.05$ in a two-tailed test.

\section{Results}

\section{Choice of taxonomy}

As expected, the number of primate species is highly significantly related to the surface area of the islands, but the slope of each relationship (z-value) is low. Choice of taxonomy did not appear to influence the slope of the species area curve (Fig. 3, Table 2). Considering the most inclusive datasets, the slopes always had $\mathrm{Z}$-values ranging between $0.13-0.16$, with coefficients of variation explaining some $41-50 \%$ of the observed variation.

Under the PSC more species can be considered island endemics (i.e. occurring on $<5$ islands) than under the BSC. Species concept has an influence on endemic species area relationships. The slope for BSC endemic species does not differ from that for BSC endemic and non-endemics combined (both being 0.16), whereas the slope for PSC endemic spe- 
cies $(0.21)$ is steeper than that for PSC endemic and non-endemics combined (0.15).

Inclusion of the Thai-Malay Peninsula or Sundaland as 'islands' has little effect on the speciesarea relationships, suggesting that the size of the dataset is large and robust enough to buffer against the effects of outliers. Likewise, exclusion of longtailed macaques from islands where it may have been introduced (i.e. those from where they have not been observed to show morphological divergence as attested by the description as subspecies) has no significant effect on the relationships be-

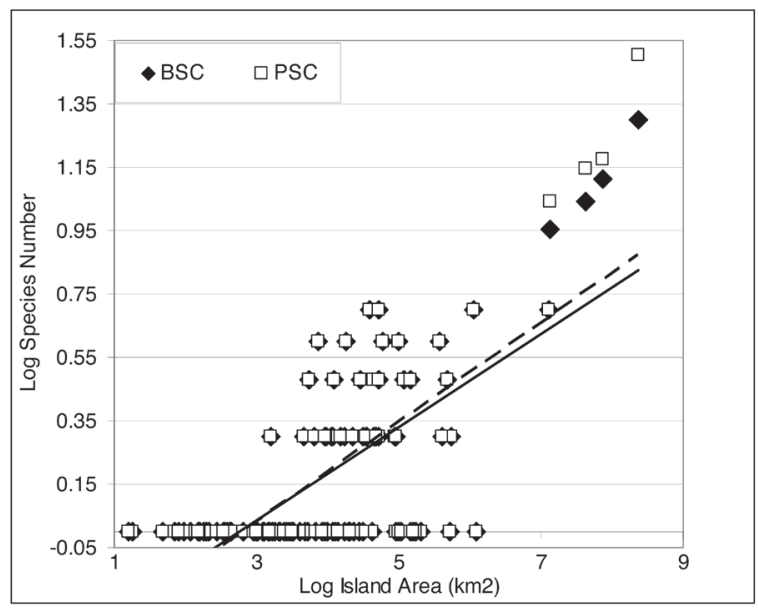

Fig. 3. Number of Primate species in Sundaland by island size, including Sundaland and the Thai-Malay Peninsula (BSC follows the Biological Species Concept - Groves 1993 and PSC follows the Phylogenetic Species Concept - Groves 2001 and updates). tween species number and surface area of the islands (Table 2).

\section{Effect of geographical variables}

Several of the predictor variables were significantly correlated: altitude vs area $(R=0.53, P=0.0001)$; altitude vs longitude $(R=0.41, P=0.001)$; area vs longitude $(R=0.31, P=0.008)$; area vs depth $(R=$ $0.36, P=0.002)$; distance to nearest island vs depth ( $R=0.39, P=0.001)$; distance to mainland vs depth ( $R=0.33, P=0.005)$; and distance to island vs distance to mainland ( $R=0.59, P=0.001)$. The predictor variables in the multiple regression model explained $19 \%$ of the variation in the number of species per island $(R=0.43, P=0.081)$, with area $(t$ $=2.309 ; P=0.025)$ and longitude $(t=-1.981 ; P=$ $0.05)$ being the strongest predictors. Our analysis of colinearity suggested that the strong correlation between longitude, altitude and area confounded the results, and we repeated the multiple regression without entering longitude and altitude as predictors. In this analysis, the predictor variables explained only $11 \%$ of the variation in the number of species per island $(P=0.05)$.

\section{Discussion}

\section{Species area relationships}

Our analysis suggests that the number of primate species on Sundaic islands is almost entirely deter-

Table 2. Relationships between Primate species richness (BSC follows the Biological Species Concept - Groves 1993 and PSC follows the Phylogenetic Species Concept - Groves 2001 and updates) and island size in Sundaland using a double log analysis. 'All areas' include Sundaland and the Thai-Malay Peninsula; 'minus possibly introduced M. fascicularis' excludes this species from all smaller islands apart from those with their own subspecies under the assumption that there is a chance that they have at one time been introduced by humans.

\begin{tabular}{|c|c|c|c|c|c|c|}
\hline Analysis & $\mathrm{N}(\operatorname{tax} a)$ & $\mathrm{N}$ (islands) & Slope & Intercept & $R^{2}$ (adj.) & $\mathrm{P}<$ \\
\hline \multicolumn{7}{|l|}{$\overline{\mathrm{BSC}}(1993)$} \\
\hline All species, all areas & 23 & 118 & 0.16 & -0.44 & 0.50 & 0.0001 \\
\hline All species, islands only & 23 & 116 & 0.13 & -0.36 & 0.42 & 0.0001 \\
\hline Endemic species only, all areas & 12 & 17 & 0.16 & -0.57 & 0.58 & 0.0001 \\
\hline \multicolumn{7}{|l|}{$\overline{\mathrm{PSC}}(2008)$} \\
\hline All species, all areas & 37 & 118 & 0.15 & -0.36 & 0.49 & 0.0001 \\
\hline All species, islands only & 36 & 116 & 0.13 & -0.34 & 0.41 & 0.0001 \\
\hline All species minus possibly intro & & & & & & \\
\hline $\begin{array}{l}\text { M. fascicularis, all areas } \\
\text { All species minus possibly intro }\end{array}$ & 37 & 77 & 0.14 & -0.42 & 0.45 & 0.0001 \\
\hline M. fascicularis, islands only & 36 & 75 & 0.11 & -0.33 & 0.36 & 0.0001 \\
\hline Endemic species only, all areas & 21 & 23 & 0.21 & -0.84 & 0.60 & 0.0001 \\
\hline
\end{tabular}


mined by island area. Degrees of isolation (as expressed by the depth of seas separating the island from the mainland and the distance of the island to mainland/nearby island) has little direct influence on the number of species. Similarly, altitude, and latitude do not have much influence on the variation in number of species. This is in broad agreement with Harcourt's (1999) findings based on a smaller dataset. The primate species-area relationships in insular Southeast Asia are thus best explained by invoking a scenario where progressively more species became extinct when sea levels rose after the last glacial maximum. This effect would have been exacerbated by even higher sea levels (1-4 $\mathrm{m}$ above present level) that occurred between 5,000 and 6,000 years ago (Thomas et al., 1999; Geyh et al., 1979; Hesp et al., 1998), which would have reduced island areas even more, and affected extinction, especially on low-elevation islands. Immigration across water as to colonise islands does not fit in this scenario. The only two species which, based on their ecology, are expected to be able to colonise off-shore islands, and even islands further away, are the long-tailed macaque and the proboscis monkey. Proboscis monkeys inhabit mangroves, swamp and riverine forests, occupying river islands (Meijaard and Nijman, 1999, 2000), and is a good swimmer. However apart from Borneo, its main distribution range, the species has been recorded on just three islands, all of which are very close to the present coastline of Borneo.

Because of its frequent proximity to human habituation, and, at least locally, its habit of feeding in open spaces, long-tailed macaques have been considered 'weed'-species (Richard et al., 1989). Furthermore it is by far the most common primate to be encountered on pet markets in Indonesia (Shepherd et al., 2004; Nijman, unpublished data). If this close proximity to humans has resulted in the introduction of macaques on small islands where they were previously not present, this may obscure real biogeographical patterns. Long-tailed macaques are the most widespread species in the region, being recorded on 105/118 islands in our dataset, including many small islands. Long-tailed macaques - which are also know by their vernacular name of crabeating macaque - can be found on a variety of coastal environs, and given enough time may reach small off-shore islands and islets unaided. The exclusion of records of long-tailed macaques from all small islands where they have not been observed to show morphological divergence (as attested by the description as subspecies) has no significant effect on the relationships between species number and surface area of the islands.

We note that both longitude and latitude are inversely correlated with the number of species per island, suggesting that species numbers decrease in a northerly and easterly direction. This effect is primarily caused by the high number of primate species on the Mentawai Islands on the far west of our study area.

\section{Taxonomy and slope}

There is a relative large difference in number of primate species in insular Southeast Asia under the BSC (23) or PSC (37). Choice of species concept had little or no effect on the species-area curves. Contrary to Isaac et al. (2004) suggesting that application of PSC as opposed to BSC will lead to a greater increase in species richness in large than in small areas applying the PSC to Primates in insular Southeast Asia leads to an increase in species irrespective of area size. The 'new' PSC species are not only described from small islands (e.g. Macaca pagensis and $M$. siberu from the Mentawai Islands: Roos et al., 2003; Ziegler et al., 2007; Presbytis natunae from Bunguran Island: Groves, 2001; Lammertink et al., 2003) but also from intermediate islands (e.g. Nycticebus javanicus from Java: Chen et al., 2006) and the largest (Presbytis siamensis and $P$. femoralis from Sumatra and the Thai-Malay Peninsula: Groves, 2001; P. chrysomelas, $P$. sabana and $P$. canicrus from Borneo: Meijaard and Groves, 2004). The hypothesis of Isaac et al. (2004) that taxonomic inflation (by applying the PSC) will lead to speciesarea curves to become steeper, giving greater analytical power, is not supported by the data on primates in insular Southeast Asia.

Choice of species concept has an effect on the positioning of primate hotspots on Borneo (Meijaard and Nijman, 2003) and indeed other species in other regions (e.g. birds in Africa: Dillon and Fjeldsa, 2005). Likewise choice of species concept did have an effect on the slope of the species-area curve when restricting the analysis to endemic species. More species can be considered endemic to a small number of islands (which can be small or large) under the PSC than under the BSC and the difference in sample size may affect the outcome of the analysis. Under the PSC several species are restricted in their distribution to (a part of) a single island only, 
including Nycticebus hilleri, Macaca pagensis, Presbytis siamensis, $P$. natunae, $P$. chrysomelas, and, while long-recognised as such, under the PSC, North Sumatra, the Mentawai Islands, North Borneo and West Java stand out even more as centres of endemism.

\section{Conclusion and avenues for further research}

Irrespective of species concept the double log value of 0.13-0.16 for primate species in insular Southeast Asia is low for land bridge islands (Williamson, 1988; Huggett, 2004), and is lower than found by Heaney (1984) for all mammals $(\mathrm{z}=0.235, \mathrm{~N}=14$ islands) or by Harcourt (1999) for primates $(\mathrm{z}=$ $0.21, N=29$ islands) in Southeast Asia. Our larger sample size in terms of islands (e.g. 4 times that of Harcourt 1999 and 8 times that of Heaney 1984) was mainly due to omission of the smaller islands but also some medium large ones (e.g. Laut 2057 $\mathrm{km}^{2}$, Bintan $1173 \mathrm{~km}^{2}$, Padang $1109 \mathrm{~km}^{2}$ ) in previous studies. In MacArthur and Wilson (1967) our z-values (0.13-0.16) fall in the range of typical nonisolated samples on the mainland (or large islands) where z-values tend to vary between $0.12-0.17$. As discussed by Whittaker and Fernandez-Palacios (2007) there are many examples that broadly support the island-mainland distinctions but there are also exceptions. The low z-value reported here may suggest that for primates the islands of insular Southeast Asia do not appear to be isolated (with frequent dispersal between islands irrespective of the depth and distance they are separated from the mainland or other large islands). Alternatively many of the smaller islands may be oversaturated, with a higher species number than would be expected by their size or conversely that the bigger islands have fewer species than expected for their size.

As noted in the introduction, a crucial parameter in studying species area relationships is an accurate knowledge of the distribution of taxa on the different islands. Among mammals, distribution ranges of primates are among the best known, and using primates it would be worthwhile to test the influence of species concept on species-area relationships in other biogeographical areas. With many new species having been described recently, the primates of Madagascar and the Neotropics (both the result of a single colonization event, 50-60 MYa and 17-37 MYa respectively followed by major radiations, Poux et al., 2005, 2006) would make excellent test cases, albeit that regions instead of islands have to be used in the analysis. Alternatively, one could test the influence of species concepts on species-area relationships using other well-known taxa, such as birds, living in insular Southeast Asia. In the latter case we expect that, as with primates, this may have little effect other than when the analysis is restricted to endemic species.

\section{Acknowledgements}

We thank the Zoological Museum Amsterdam for organising the 'Biogeography: explaining and predicting species distributions in space and time' symposium. VN thanks students of Module P20101 (Primate diversity and biogeography) of the M.Sc in Primate Conservation at Oxford Brookes University for insightful discussions. Dr H Chatterjee and an anonymous reviewer made constructive comments on the paper.

\section{References}

Beaufort LF. 1926. Zoogeographie van den Indischen Archipel. Haarlem: De Erven F. Bohn.

Bird M, Taylor D, Hunt C. 2005. Palaeoenvironments of insular Southeast Asia during the Last Glacial Period: a savanna corridor in Sundaland? Quaternary Science Reviews 24: 2228-2242.

Brandon-Jones D. 1996a. The Asian Colobinae as indicators of Quaternary climatic change. Biological Journal of the Linnean Society 59: 327-350.

Brandon-Jones D. 1996b. Presbytis species in sympatry in Borneo versus allopatry in Sumatra: an interpretation. In: Edwards DSEA, ed. Tropical Rainforest Research - Current Issues. Dordrecht: Kluwer, 71-76.

Chatterjee HJ. 2006. Phylogeny and biogeography of gibbons: A dispersal-vicariance analysis. International Journal of Primatology 27: 699-712.

Chen JH, Pan D, Groves C, Wang YX, Narushima E, FitchSnyder H, Crow P, Thanh VN, Ryder O, Zhang HW, Fu YX, Zhang YP. 2006. Molecular phylogeny of Nycticebus inferred from mitochondrial genes. International Journal of Primatology 27: 1187-1200.

Chivers DJ. 1980. Malayan forest primates. Ten years' study in the tropical rain forest. New York: Plenum Press.

Chu JH, Lin YS, Wu HY. 2007. Evolution and dispersal of three closely related macaque species, Macaca mulatta, M. cyclopis, and M. fuscata, in the eastern Asia. Molecular Phylogenetics and Evolution 43: 418-429.

Cracraft J. 1983. Species concepts and speciation analysis. In: Johnston RF, ed. Current ornithology. Volume 1. New York: Plenum Press, 159-187.

Dillon S, Fjeldsa J. 2005. The implications of different species concepts for describing biodiversity patterns and assessing conservation needs for African birds. Ecography 28: 682-692. 
Gathorne-Hardy FJ, Syaukani, Davies RG, Eggleton P, Jones DT. 2002. Quaternary rainforest refugia in south-east Asia: using termites (Isoptera) as indicators. Biological Journal of the Linnean Society: 75, 453-466.

Geissmann T, Groves CP, Roos C. 2004. The Tenasserim Lutung, Trachypithecus barbei (Blyth, 1847) (Primates: Cercopithecidae): Description of a live specimen, and a reassessment of phylogenetic affinities, taxonomic history, and distribution. Contributions to Zoology 73(4): 271-282.

Geyh MA, Kudrass HR, Streif H. 1979. Sea-level changes during the late Pleistocene and Holocene in the Strait of Malacca. Nature 278, 441-443.

Groves CP. 1993. Order primates. In: Wilson DE, Reeder DM, eds. Mammal species of the world: a taxonomic and geographic reference. Washington, DC: Smithsonian Institution Press, 243-278.

Groves CP. 2001. Primate taxonomy. Washington, DC: Smithsonian Institution Press.

Groves CP. 2004. The what, why and how of primate taxonomy. International Journal of Primatology 25: 1105-1126.

Hanebuth T, Stattegger K, Grootes PM. 2000. Rapid flooding of the Sunda Shelf: a late-glacial sea-level record. Science 288, 1033-1035.

Harcourt AH. 1999. Biogeographic relationships of primates on South-East Asian Islands. Global Ecology and Biogeography 8: 55-61.

Harcourt AH. 2000. Coincidence and mismatch of biodiversity hotspots: a global survey for the order Primates. Biological Conservation 93: 163-175.

Harrison T, Krigbaum J, Manser J. 2006. Primate biogeography and ecology of the Sunda Shelf Islands: a paleontological and zooarcheological perspective. In: Lehman SM, Fleagle JG, eds. Primate biogeography, progress and prospects. New York: Springer, 331-372.

Heaney LR. 1984. Mammalian species richness on islands on the Sunda Shelf, Southeast Asia. Oecologia (Berlin) 61: 11-17.

Heaney LR. 1985. Zoogeographic evidence for Middle and Late Pleistocene land bridges to the Philippine islands. Modern Quaternary Research SE Asia 9: 127-143.

Heaney LR. 1986. Biogeography of mammals in SE Asia: estimates of rates of colonization, extinction and speciation. Biological Journal of the Linnean Society 28: 127-165.

Heaney LR. 1991. A synopsis of climatic and vegetational change in Southeast Asia. Climatic Change 19: 53-61.

Hesp PA, Chang CH, Hilton M, Chou ML, Turner IM. 1998. A first tentative Holocene sea-level curve for Singapore. Journal of Coastal Research 14: 308-314.

Holloway JD, Hall R. 1998. SE Asian geology and biogeography: an introduction. In: Hall R, Holloway JD, eds. Biogeography and geological evolution of SE Asia. Leiden: Backhuys Publishers, 1-23.

Huggett RJ. 2004. Fundamentals of biogeography. Abingdon: Routledge.

Inger RF, Voris KV. 2001. The biogeographical relations of the frogs and snakes of Sundaland. Journal of Biogeography 28, 863-891.

Isaac NJB, Mallet J, Mace GA. 2004. Taxonomic inflation: its influence on macroecology and conservation. Trends in Ecology and Evolution 19: 464-469.
Lammertink M, Nijman V, Setiorini U. 2003. Habitat use, Red List status and conservation of the endemic Natuna leaf monkey (Presbytis natunae) on Bunguran Island, Indonesia. Oryx 37: 472-479.

Molengraaff GAF, Weber M. 1920. Het verband tusschen den Pleistoceenen ijstijd en het ontstaan der Soenda-zee en de invloed daarvan op de verspreiding der koraalriffen en op de fauna. Verslagen der Afdeeling Natuurkunde 28, 497-544.

Myers N, Mittermeier RA, Mittermeier CG, Da Fonseca GAB, Kent J. 2000. Biodiversity hotspots for conservation priorities. Nature 403, 853-858.

MacKinnon K, Hatta G, Halim H, Mangalik A. 1996. The ecology of Kalimantan. Singapore: Periplus Editions.

Mayr E. 1942. Systematics and the origin of species. New York: Columbia University Press.

MacArthur RW, Wilson EO. 1967. The theory of island biogeography. Princeton: Princeton University Press.

Meijaard E. 2003a. Solving mammalian riddles. a multi-disciplinary reconstruction of the Tertiary and Quaternary distribution and dispersal of selected mammals and their palaeoenvironments in Sundaland and Wallacea. PhD dissertation. Canberra: Australian National University.

Meijaard E. 2003b. Mammals of Southeast Asian islands and their Late Pleistocene environments. Journal of Biogeography 30: 1245-1257.

Meijaard E, Groves CP. 2004. The biogeographical evolution and phylogeny of the genus Presbytis. Primate Report 68: 71-90.

Meijaard E, Nijman V. 1999. Distribution and conservation of the proboscis monkey Nasalis larvatus in Kalimantan, Indonesia. Biological Conservation 92: 15-24.

Meijaard, E. Nijman V. 2000. Distribution and conservation of the proboscis monkey (Nasalis larvatus) in Kalimantan, Indonesia. Biological Conservation 92: 15-24.

Meijaard E, Nijman V. 2003. Primate hotspots on Borneo: Predictive value for general biodiversity and the effects of taxonomy. Conservation Biology 17: 725-732.

Nekaris KAI, Jaffe S. 2007. Unexpected diversity within the Javan slow loris trade: implications for slow loris taxonomy. Contributions to Zoology 76: 187-196.

Nijman V. 1997. On the occurrence and distribution of Presbytis comata (Desmarest 1822) (Mammalia: Primates: Cercopthecidae) on Java, Indonesia. Contributions to Zoology 66: 247-256.

Nijman, V. 2000. Geographical distribution of ebony leaf monkey Trachypithcus auratus (Geoffroy Saint Hilaire 1812) (Mammalia: Primates: Cercopthecidae). Contributions to Zoology 69: 157-177.

Nijman, V. 2004. Conservation of the Javan gibbon Hylobates moloch: population estimates, local extinctions, and conservation priorities. The Raffles Bulletin of Zoology 52: $271-280$.

Nijman V. 2006. In-situ and ex-situ status of the Javan gibbon and the role of zoos in conservation of the species. Contributions to Zoology 75: 161-168.

Poux C, Madsen O, Marquard E, Vieites DR, de Jong WW, Vences M. 2005. Asynchronous colonization of Madagascar by the four endemic clades of Primates, Tenrecs, Carnivores, and Rodents as inferred from nuclear genes. Systematic Biology 54: 719-730. 
Poux C, Chevret P, Huchon D, de Jong WW, Douzery EJP. 2006. Arrival and diversification of caviomorph rodents and platyrrhine primates in South America. Systematic Biology 55: 228-244.

Preston FW. 1960. Time and space and the variation of species. Ecology 41: 611-627.

Preston, FW. 1962. The canonical distribution of commonness and rarity. Ecology 43: 185-215.

Roos C, Ziegler T, Hodges JK, Zischler H, Abegg C. 2003. Molecular phylogeny of Mentawai macaques: taxonomic and biogeographic implications. Molecular Phylogenetics and Evolution 29: 139-150.

Rowe N. 1996. The pictorial guide to the living primates. East Hampton, NY: Pogonias Press.

Shepherd CR, Sukumaran J, Wich SA. 2004. Open Season; An analysis of the pet trade in Medan, Sumatra 1997-2001. Kuala Lumpur: TRAFFIC Southeast Asia.

Steiper ME. 2006. Population history, biogeography, and taxonomy of orangutans (Genus: Pongo) based on a population genetic meta-analysis of multiple loci. Journal of Human Evolution 50: 509-522.

Thomas M, Thorp M, McAlister J. 1999. Equatorial weathering, landform development and the formation of white sands in north western Kalimantan, Indonesia. Catena 36: 205-232.
Tjia HD. 1980. The Sunda shelf, Southeast Asia. Zeitschrift für Geomorphologie 24: 405-427.

Voris HK. 2000. Maps of the Pleistocene sea levels in Southeast Asia: Shorelines, river systems and time durations. Journal of Biogeography 27: 1153-1167.

Wallace AR. 1876. The geographical distribution of animals Vol. 2. London: MacMillan.

Whitmore TC. 1987. Biogeographical evolution of the Malay Archipelago. Oxford: Clarendon Press.

Whittaker RJ, Fernandez-Palacios JM. 2007. Island biogeography. Ecology, evolution, and conservation. Oxford: Oxford University Press.

Wilcox BA. 1980. Insular ecology and conservation. In: Soul ME, Wilcox BA, eds. Conservation biology. An evolutionary-ecological perspective. Sunderland: Sinnauer, 95-117.

Zain BM 2001. Molecular systematics of the genus Presbytis. PhD. dissertation. New York: Columbia University.

Ziegler T, Abegg C, Meijaard E, Dyah Perwitasari-Farajallah D, Lutz W, Hodges KJ, Roos C. 2007. Molecular phylogeny and evolutionary history of Southeast Asian macaques forming the $M$. silenus group. Molecular Phylogenetics and Evolution 42: 807-816.

Received: 17 March 2008

Accepted: 27 June 2008 